\title{
THE UNKNOWN MAX WEBER: A NOTE ON MISSING TRANSLATIONS
}

Alan Sica

University of Kansas

and

University of Chicago

Mid-American Review of Sociology, 1984, Vol. IX, No. 2:3-25

This research note shows that some important interpreters of Weber's work to American sociologists have made highly selective use of his writings. The case of Parsons is briefly treated. Then detailed examination is made of what Weber wrote during his professional lifetime, how much of it has been collected into the standard works, and how much of that has been translated. It is thereby suggested that the American view of Weber is based on fragmentary evidence.

Scholarship directly concerning Max Weber has not abated in recent years, even though there were already by 1976 over 2,300 published works which bore on Weber the man, his work, or his intellectual and personal setting (Seyfarth and Schmidt, 1977:165). Weber scholarship seems to come in cycles. Between 1968 and 1972, a flurry of monographs appeared, numbering more than a dozen in English alone. The mid-70's were quiet years, except for Marianne's indispensable biography, finally translated in 1975. But since 1979, when Guenther Roth and Wolfgang Schluchter published Max Weber's Vision of History (University of California), another flood has issued from publishers here, in England, even from Tokyo, adding more than 20 additional Weber monographs to the shelves. ${ }^{1}$ Much of this work can be divided into two streams, one which partakes of his specific ideas or sociological approach, then applies them to a contemporary substantive "problem," the other of a hermeneutical cast, addressing the texts themselves in the interest of some theoretical question. While the former apparently dominated research in the 1950's and early 1960's, when sociologists hopefully "mined" the classics for ideas to test empirically, during the last 15 years the pendulum has swung toward a higher proportion of books which speak directly to the loci classici. Though these subsets of Weberians are not totally exclusive of one another, it is 
no secret that practitioners of the first style consider the latter somewhat pedantic, while their opposite numbers harp on the "a-contextuality" that infects empirical research "using" Weber as its theoretical inspiration or legitimation. Happily, the problems associated with this disjunction bear indirectly upon the present note; yet for those who take their research impetus from several pages (or paragraphs) on bureaucracy, power, charisma, and so on, what follows may seem less worrisome than for others whose work turns more explicitly around Weber's writings themselves instead of various empirical problems or hypotheses to which they might be connected.

The purpose of what follows is to show that common perceptions in the U.S. of what is known about Weber's lifework-beyond the small circle of Weber specialists-are incongruent with the body of work as it actually exists. It is widely assumed that "we know Weber," that if any classical figure has been more thoroughly probed theoretically by American sociology, it could only be Marx. And given the sheer quantity of secondary works, one can sympathize with those who call for a moratorium on Weber exegesis. Yet this plaint is aimed more at commentators and polemicists than at Weber himself. How much of his work we actually know and use remains unspecified. Understandably, it is often assumed that with 22 volumes translated in to English bearing his authorship (see References), we must by now have access to most of his writings, and certainly to any of importance. This is unfortunately not accurate. ${ }^{2}$

If we neither have most of Weber's works in English, thus in theoretical discourse, nor all of those which are potentially important, an explanation for this perduring illusion is called for. Psychologistic motivations of one kind or another too easily present themselves, yet probably do account for some of the slippage between what is believed and what is fact. But more compelling reasons beyond the limits of scholarly fright or sloth come to mind; let us examine one. Between 1937 and the early 1970s probably no one introduced more novitiates to Weber than Parsons. Part III of his Structure of Social Action (pp. 500-694) offers a broad-gauged dissection of Weber's sociology, especially the sociology of religion. ${ }^{3}$ When one adds Bendix's Max Weber (1962) to Parsons' treatment, it is possible to account for much of what many American sociologists knew about Weber. Even for those who read carefully several works in translation, Bendix and Parsons doubtlessly guided many readers of each book. This had its costs, particularly given the peculiarities of Parsons' translations (frequently remarked upon, e.g., Bendix, 1962:272n-273n; Roth, 1976:316-317).
Without going into the specifics of translation problems, it is instructive to examine Parsons' rendition of Weber's thought in 1937 strictly in terms of his source materials. ${ }^{4}$ Four chapters treat Weber's Protestant ethic thesis, the comparative religion, his methods, and the "systematic theory" (chapters 14, 15, 16, and 17 respectively). Examination of Parsons' citations from the primary materials is illuminating vis-à-vis what I am calling the "unknown Weber." The chapter dealing with religion and capitalist growth, as one would expect, draws overwhelmingly from The Protestant Ethic (21 references), heavily concentrated in the first 100 pages of the book, with no explicit use made of the technical endnotes (Weber, 1958:185-284), judged by some as the most striking feature of the work (including Marianne Weber [1975: 339] regarding Beruf qua philological problem; see Weber, 1958:204206). From Vol. 1 of the Religionssoziologie, four references come, and four more originate in a ten-page section of Wirtschaft und Gesellschaft on bureaucracy (Weber, 1968a:III, 956ff). Chapter 15, on comparative religion, is heavily indebted to the first volume of Religionssoziologie (27 references), many arising from the last several chapters of Weber's analysis of Confucianism and Taoism (Weber, 1951:107ff). Volume 2 of the sociology of religion (Weber, 1958c) produces about two-thirds as many references, the core of which Parsons selected from Weber's comments on the historical development of castes (Weber, 1958c: $123 \mathrm{ff})$. And rounding out the chapter, ten more citations are selected from a small segment of Wirtschaft und Gesellschaft dealing with the origins of religion (Weber, 1968a:II, 399ff). Chapter 16 on Weber's methodology is less easily assayed since Parsons, by his own admission, relied heavily on von Schelting's classic exposition (19.34). Thirty-three references are made to Weber's collected essays on method (1922a), many originating in what has since become known as Weber's "objectivity" essay (Weber, 1949:50-112). Parsons simultaneously follows von Schelting's lead closely, and cites his book 24 times. And finally, the last chapter, on Weber's "systematic theory" as Parsons calls it, owes most of its inspiration to another highly selective reading of Wirtschaft und Gesellschaft ( 55 citations, over half of which can be found in the first 32 pages of the German edition).

This trot through Parsons' source usage is meant to show only that the "Weber" presented in his influential commentary bears a thin referential relation to the complete Weber. This does not mean that ipso facto Parsons' treatment is invalidated; nor does this fact contribute meaningfully to the ongoing process of "de-Parsonizing" (Cohen, 
et al., 1975). One cannot easily argue against the proposition that interpretations are usually based on selective readings, of ten for sheerly practical reasons. But the point worth making-and one which differs distinctly from disputing Parsons' translations or his rendering of Weber's ideas-is simple: Parsons' reading is much more selective than even his sternest detractors have hinted. One must question an author's reliance for interpretation or translation upon a given text "A," when texts " $B$ " through " $F$ " speak to the issue at hand just as compellingly, if not more so. Students of social thought cannot assume that commentators upon whom they rely have chosen the most germane or representative texts from a given universe of possible sources when fashioning their argument. And this returns us to the need for a precise description of Weber's oeuvre, in response to the errors of believing that commentaries have represented his theory and substantive research exhaustively, or that English translations have made most of Weber's work available to readers who reject secondary studies, or who wish to augment them with primary sources.

Perhaps the best way to view Weber's lifework is to divide the mass into three periods. The first begins in 1889 and ends with Weber's emotional collapse in 1898 . The second starts with Weber's reentry into scholarly polemics in 1903 and closes with his public withdrawal from the same in 1910. The last period takes us from 1911 to his death in 1920. It is through portions of the material written during the final segment (and published almost entirely posthumously) that Weber is still best known to American sociology, with the notable exception of The Protestant Ethic (1904-05). [See Summary Table, p. 5]

Between 1889 and 1898 Weber.published an enormous amount and variety of sociological, political-economic, and historical writing. His dissertation on late medieval trading companies in the Mediterranean (1889) is reasonably well-known by name, but has not yet substantively penetrated American sociology since most scholars rely upon capsulizations for their knowledge of the work (e.g., Bendix, 1962:1-2; Roth, 1968:xxxiv-xxxvi). Very quickly he composed an habilitation on the history of agrarian practices in Rome (1891) which won immediate acclaim in Germany, but was not included in Weber's collected works and is therefore ignored today. (It is forthcoming as Volume 2 of the Max Weber Gesamtausgabe.) Bendix (1962) ignores it in his intellectual portrait, leaving Roth's short treatment (1968:xxxvi-xl) as the most accessible in English. A longer exegesis was provided a generation ago by Paul Honigsheim in journals not commonly known to sociologists
SUMMARY TABLE

Period German Texts Published English Translation $\%$

1889-1898

2,063 pages $+J$ ugendbriefe 22 pages

54 items

II $\quad 1903-1910 \quad 1,516$ page

49 items

940 pages

$64 \%$

$\begin{array}{ll}1911-1920 & \begin{array}{l}1,633 \text { pages } \\ 78 \text { items }\end{array}\end{array}$

4,008 pages

$78 \%$

IV Posthumous 5,115 pages*

9 volumes
*2,092 pages of published work remain uncollected; the actual lifework total is about 7,738 pages, of which 48 percent is in English. 
(1946, 1948, 1949). With hardly a breath, Weber then directed what at the time was a huge survey research project on behalf of the Verein für Sozialpolitik (1892), in order to ascertain the state of agrarian economy and social structure east of the Elbe, a hot political issue of the era. Results of the survey were published as an 891-page volume in the proceedings of the Verein, all of which Weber either wrote, compiled, or edited for publication. (For some details about the political setting of the study, see Oberschall, 1965:21-27, passim.) The volume has not been reprinted, and like the habilitation, is not represented in the collected works. (As Volume 3 of the Max Weber Gesamtausgabe, it comes to 1100 pages.) It is very unlike Weber's work of the third and best known period. For instance, Weber compiled over 200 pages of tables for this volume. There are indeed other works of the first period in which he used conventional tabular representation of data, but none of this dimension. Needless to say, the publication of the research report established Weber as the primary authority on "the agrarian problem," at the age of 28. For those who find it hard to conceive of Weber scrutinizing masses of empirically derived data, this volume should serve as an antidote to their scepticism. (For a summary, see Bendix, 1962: 14-23).

The next major publication from the first period includes a study of the stock and commodity exchange published in segments between 1894 and 1896, totalling 390 pages, only 65 of which found their way into the collected essays. Very little comment has been made upon this sizeable work; as usual, the exception is Bendix (1962:23-29). In addition to these major works, Weber managed to publish numerous position papers, book reviews, contributions to symposia, and so on. With the help of the definitive bibliography of Weber's work (Käsler, 1975:705-708), it can be shown that during the first period of creativity, Weber published 54 items totalling 2,063 pages of scholarly material, excluding, of course, his Jugendbriefe (1936:375 pp). Of this, 347 pages $(17 \%)$ have been included over the years in various volumes of the Gesammelte Aufsätze and other posthumous works (1920, 1921a, $1921 \mathrm{~b}, 1921 \mathrm{c}, 1922 \mathrm{a}, 1922 \mathrm{~b}, 1923,1924 \mathrm{a}, 1924 \mathrm{~b})$. And of the total for this period, American sociologists presently have access to 22 pages in translation (the famous essay on the decline of Rome [1950]), or just over one percent. Thus, we see that Weber's promethean first period of scholarly production might accurately be entitled-so far as American sociology is concerned-his "lost decade." It is as if he was academically in 1903 when the first of his notable essays on Roscher, Knies, and the Protestant Ethic appeared.

It is one thing to show that we know little about Weber's early work, but another to explain why this ignorance might be detrimental to our work. An efficient way to demonstrate how truly rich, theoretically and substantively, these writings are is to recover the unsurpassed essays of Paul Honigsheim (noted above), whose On Max Weber (1968) finally established him in the U.S. as a Weber authority posthumously, 48 years after he had first published essays on his legendary friend. Honigsheim was one of the select few who participated in the vigorous Weber-Kreis in Heidelberg. Weber approvingly cited his dissertation on Jansenism in The Protestant Ethic, ${ }^{5}$ and the younger man's frequent visits to Weber's large home on the Neckar are recorded in Marianne's biography. ${ }^{6}$ On the basis of this intimate knowledge about Weber, his colleagues, his personal style and intellectual concerns, Honigsheim wrote over the years a series of masterful essays, the first of which appeared almost immediately after Weber's death in 1920, the last left in manuscript in 1963, just prior to the author's own end. ${ }^{7}$ But since many of them have remained either untranslated or in journals seldom consulted by American students of Weber-as evidenced by the infrequency of Honigsheim citations in the literature-this remarkable portrait of his colleague as man and sociologist has suffered neglect, when compared to those of others. ${ }^{8}$ This is not only unfortunate on the grounds that Honigsheim alone, of all these chroniclers (except Loewenstein), knew Weber and was esteemed by the master of Heidelberg, but also because certain of his essays open up portions of Weber's work to English-language scholars that are otherwise obscured through a lack of translations.

Honigsheim published in the late 1940's a set of four essays which address what I have called Weber's "lost decade," this segment of a promethean career unknown to us; the period during which Weber established his reputation in Germany as the most versatile and brilliant younger social scientist. It was, in fact, these very studies which drew young men like Honigsheim, Ernst Bloch, Georg Lukács, and Karl Loewenstein to Weber after his partial recovery in 1903. To get at these early writings, and especially for those involving ancient history, Honigsheim's solid essays are indispensable, little gems which have virtually escaped notice since their publication 30 years ago.

The first of the group, "Max Weber as Rural Sociologist," concisely treats Weber's essays on Russia, Poland, and other works in 
economic history. With rare exception, ${ }^{10}$ little of the material Honigsheim dealt with has been translated or commented upon in subsequent secondary studies. Among the topics Honigsheim covered are the "feoffment in trust" (Fideikommis) and the importance of this feudal anachronism in late 19th century Europe, and Weber's interpretation of the Serbian Zadruga and the Russian Mir. This initial statement about Weber in an American journal still offers a point of departure for students wishing to probe Weber's celebrated and misunderstood distaste for traditional Slavic social structure. (He was at the same time, however, a champion of revolutionary movements, particularly following the events of $1905 .{ }^{11}$ ) The only scholar who more recently has assayed Weber's rural sociology based most of his conclusions on Honigsheim's spadework. ${ }^{12}$

Two years later Honigsheim turned his attention toward "applied anthropology." 13 Here again one finds illumination about Weber's interest in subjects which have too often been ignored in favor of the "warhorses"-bureaucracy, stratification, the market, and so on. For instance, Honigsheim aggressively makes a case for Weber's intellectual commitment to the study of race, ethnicity, nationalism as mediated by ethnic attachments, social policy formation, handicraft economies, comparative social structures, and also what he calls "Ethno-Politics" or "Ethnic Social Politics" (28). Honigsheim guides the reader through a set of essays which have mostly eluded translators, especially those in which Weber combines the results of empirical research with prognostications about the political fates of given countries and areas. His essays on Poland, Prussia, Russia, Bavaria, Bismarck's foreign policy, the nation-state, the role of the national president, the condition of agricultural laborers, and various racialist theories (of which Weber held a low opinion) are among these.

The two earlier essays apparently served as the working papers for the third, "Max Weber as Historian of Agriculture and Rural Life," 14 a minor masterpiece of exegesis and comparative inquiry. It is comparative since Honigsheim carried out the enormous task not only of concisely stating Weber's achievements in the field, but also showed whose ideas Weber used, whether and how he modified them in his own research, which later scholars made use of Weber's major notions, and to what degree. This immense labor of love requires nearly 24,000 words and four mighty tables, on which the author directly relates Weber's work to that of dozens of writers from all major European countries, and through scores of research monographs. ${ }^{15}$ It is a performance in the sociology of knowledge rivalled by few in the genre. In addition to the prodigious tabular layout, Honigsheim also composed notes to the article which must be read to be believed. In the first, pagelong footnote, for example, he writes, "The following authors seemingly deal with the same matters in some of their books as Weber, but actually they do not mention him, even in their footnotes and bibliographies, and accordingly they can be omitted [from Honigsheim's consideration] : . . .," whereupon sixty-two scholars from the U.S., England, France, Germany, China, Russia, and elsewhere are listed alphabetically (180n).

The essay begins by enumerating the "eleven fundamentals" of Weber's epistemology (10), certainly the most parsimonious report of this material one is likely to find. Thereafter Honigsheim immediately begins his long journey, during which he elucidates Weber's work on Pre-State Society, Oriental and Pre-Occidental State Cultures, Classical Antiquity, and the Christian World. To do this he must range over Weber's entire output, but as before, he concentrates on the half-dozen historical and empirical studies which Weber wrote before his debilitation in 1898. What is most useful for today's student, whether of Weber or of historical sociology in general, is the parsimony with which Honigsheim presents a deluge of factual and theoretical information. This is especially vivid in the tables, where one column of each is used to state propositional theories, noting whether they were accepted by Weber after enunciation by his predecessors. By using this format, Honigsheim makes it easy for the reader to follow important notions from one historian to another, and from this country to that (for instance, about changing family structure through history). Also notable are the subdivisions within each of the four major areas of historical interest, for example, animal husbandry, nomadism, land communism, seignorial property, the matrilinear family, and so on, all under the first topic, "Pre-State Society" (182ff). This article is in a class alone, for no other (in English) has attempted to juxtapose Weber's historical and theoretical analyses of pre-modern societies with those of his contemporaries and immediate followers to this extent and with this completeness. Not only can one quickly "locate" Weber in the intellectual current of his time, it is also simple to learn about his discoveries regarding a range of historical phenomena not often associated with his name (e.g., the Etruscans, or the powerlessness of handicraftsmen in ancient Greece). Had Honigsheim written nothing else on his mentor, 
his reputation as a Weber scholar would have been assured through wide dissemination of this one article, something which unfortunately did not occur.

The last of the four articles might best be thought of as a minor corrective and addendum to Marianne's biography. In "Max Weber: His Religious and Ethical Background and Development,"16 we learn things about Weber which in Marianne's somewhat recondite account lay beneath the surface-for instance, that Weber's pessimism about "man's perceptive capacity" and "inborn goodness" resonate with Kant's in Religion Within the Limits of Reason Alone (235), but that the major difference between the two stemmed not from arid epistemology, but from differing emotional responses to Pietism and the conception of the tragic. Honigsheim cites as his basic references for the article remarks in Weber's letters and his last two speeches, information provided by Marianne, and the author's own memories. Though many of Weber's letters have been available for some time, ${ }^{17}$ Honigsheim remains one of the few commentators to have consulted them to any extent. Perhaps the greatest service this article performs is in sorting out, definitively one might think, the thorny questions about Weber's intellectual and emotional attachment to his Pietist heritage in conflict with his neo-Kantian intellectualism. A careful reading of this last essay helps tremendously in disclosing the "tension" in Weber's life and work which resulted from the perpetual collision of "fire and ice": the "irrational" components of his religious heritage and familial dilemmas smashing against the steely edifice of his professional method and goals. Honigsheim relates Weber's passion for Dostoevski and Schopenhauer to his larger Weltanschauung, and by taking these sorts of interpretive risks, softens the lines of Weber's famous humorless visage.

Between the first and second periods (1898-1902), it was long believed that Weber wrote virtually nothing. This mistaken view, perpetuated by Marianne Weber's bibliography (1926:715-719) which lists no works for this period, was corrected in 1975 when Käsler published his Weber bibliography. A half-dozen items were listed (1975:708-709) for the first time, but they amount to little substantively.

Weber published during the second period (1903-1910) some of his most tortuous writing, particularly concerning methodology. $\mathrm{He}$ also set off an academic debate which in its intensity and duration has had few peers, concerning the relation between religious ideas and capitalist accumulation. And finally, he established himself once again as an historian of antiquity via a small masterpiece (1909), which was only recently translated into English (1976). But even with the series of recent additional translations (Weber, 1975; 1977; 1978), of the original 1,516 pages of German from the second period, thus far over 38 percent remains in the original. It is true, however, that with 938 pages of the German translated, this second period of Weber's research has been best served of the three for its American audience. It is more amazing perhaps that only three percent of the total has not been collected in one of the posthumous volumes, particularly when we recall the corresponding figures from his "lost decade."

Weber's "output" during the last ten years of his life is phenomenal by any standard, though most of it was not printed before his death. It is during this period that he moved from the extraordinary pedanticism of the century's first decade into a style of exposition virtually free of footnotes, references, and other appurtenances of German scholarship. And, as already mentioned, it is the writing of this period which informs most "Weberian sociology" of the American type. Through 1919 Weber published 1,633 pages, some of it in a long series of newspaper articles concerning the First World War, the only instance when Weber took his sentiments to the public in a sustained manner. The essay from Logos on his Katgorienlehre, essays on foreign affairs, the comparative religion studies on Hinduism, Buddhism, and Judaism, essays on value-freedom and socialism all number among his published works of the period. English translators have done their work rather well, giving us nearly 79 percent (1,284 pages) of the original, and translating all the theoretically important material. They have omitted virtually all the politically significant works, however. A decidedly different picture emerges when we consider not only translations of works published during the final creative period, but rather translations of all materials written between 1911 and 1920, and thereafter collected by Marianne Weber and others.

In order to assess how far English-language students have penetrated Weber territory in this regard, it is most efficient to address each of the posthumous works separately. The volumes of interest, of course, are as follows: three volumes on religion (1920-1921), one each on politics (1921a), methodology (1922a), economic history lectures (1923), social and economic history essays (1924a), sociology and social policy (1924b), and Wirtschaft und Gesellschaft (1921b, 1922b). Nearly all these volumes have gone through multiple editions and printings. Using the latest of each, we find that Weber's German editors have assembled 5,115 pages of his scholarship in edited form. Whereas this 
ought probably to be greeted with joy by American Weberians, if we check on available translations, the glee is diluted somewhat. The sociology of religion has come to us completely translated, albeit under various American titles, and at the hands of several translators. The essays on politics (third edition), however, number 34 (586 pages), of which one has been fully and four others partially brought into English, leaving nearly 400 pages in German. (It should also be remembered that this volume does not by any means contain all of Weber's political works.)

Of the seven volumes of collected Aufsätze, the one most favored with translations has been the Wissenschaftslehre (methodology). With recent versions in English of Roscher and Knies (1975) and the Critique of Stammler (1977), and with a master's thesis given over to a translation of the Logos piece (1970) that is now a journal article (Graber, 1981), just one essay had, until the translation now offered, been omitted. The availability of his methodological essays in English for some time has served to produce a skewed distribution of American Weber scholarship toward such issues. As has been pointed out by others, this fascination with value-freedom, the nature of the ideal-type and Verstehen, the uses of nominal categories, and the like, has figured much more centrally in our own view of Weber than in his view of himself. He all but fell totally silent on such matters after 1910 and considered "epistemologists" of social science-including his friend Rickert -something of a bore. Not unlike the ubiquitous sociological pragmatists of today, he was more interested in "doing sociology" than in warming up for it with scholastic debates over method. Also interesting by somparison is the speed of composition. and, one might argue, the attendant sloppiness evidenced in these works when juxtaposed with his substantive historical/comparative research (on ancient civilizations, the market, Roman agrarian life, medieval trade, and so on), i.e., just those works most slighted by his American readers.

The only title of this group which has finally received definitive editorial treatment is Wirtschaft und Gesellschaft. With Winckelmann's new "third volume" given entirely to annotations, we can hope for no better scholarly tool with which to approach Weber's Hauptwerk (1976). The Munich lectures on economic history (1923) have recently been reissued in English (1981), and though the weakest in scholarly terms, represent the oldest contribution to Weber's writing in translation. It is in the last two volumes of the series, however, that a good deal of the unknown Weber resides. Until 1976 and the translation of
Agrarverhaltnisse im Altertum, only one of Weber's essays on social and economic history (1924a) was in English, and five (96\% of the book) were not. It might also be guessed that since the new, hefty translation (pp. 1-288 from the German edition) was brought out by a small publisher in London, many American sociologists who warm to Weber's name will remain ignorant of this important monograph. As it is, four more essays (246 pages) are left unattended, including his dissertation and essays on agrarian workers in Prussia. And lastly we reach the most shabbily treated of all Weber's works, on "sociology and social policy" (1924b), which includes much of his most "empirical" research. Again, until recently (1971) only one small essay (on socialism) had become available to Americans. This sorry condition has been ameliorated only a little since Weber's "Methodological Introduction to the Study of Occupational Careers and Mobility Patterns" came into English. One of the most interesting empirical studies Weber ever did (in summer, 1908, at a relative's textile factory in Oerlinghausen), has strangely escaped translation. Its length and detail (nearly 200 pages) make it a suitable candidate for the fresh series of Weber translations, particularly for students of industrial sociology. All told, 432 pages $(83 \%)$ of this volume have stayed in German over the last half-century. Perhaps the Weber translation project said to have begun at Cambridge Universitywhich aims to emulate in scope the Marx/Engels Collected Works-will remedy this gap.

It should also be noted that several important ancillary sources of Weber's writing resist translation. The Jugendbriefe have already been mentioned. Perhaps the most exciting is the collection of personal documents, excerpts, plus commentary, published in 1964 by Baumgarten (who, it has been claimed, will publish another selection of 300 Weber letters; see Green, 1974:xiii). By my calculation, this collection makes public about 143 pages of hitherto scattered or private material. Two intriguing snippets have just been translated (1978b), one on Weber's feelings about Freudianism, another revealing his view of biology's relation to sociology. Finally, Johannes Winckelmann has gathered contemporary critiques of the Protestant Ethic thesis along with Weber's responses (1968b).

It is time for a final quantitative reckoning of what is readily available from Weber's lifework and what is not. To begin with, there remain approximately 2,092 pages of material uncollected, unedited, and unreprinted. Some 287npages of manuscript are reported by Käsler to be in various archives (1975:719). When this is added to writings 


\section{Mid-American Review of Sociology}

reviewed above, it appears that Weber's entire output came to about 7,738 pages, excluding some correspondence. American readers using all those works which are translated (including the numerous duplications) can account for about 3,726 pages of the German. This is 48 percent of the entirety. In sheer quantitative terms, then, American sociology's conception of Max Weber-to the extent it revolves around English translations-speaks for merely half of the man's actual corpus. If one further assumes that most practitioners learned their Weber before 1975, and if one therefore excludes translations which have been published since then, Weber's untranslated works grow to 60 percent.

It is obvious that these gross calculations leave a variety of crucial hermeneutical questions about Weber scholarship unaddressed, e.g., are extant translations reliable, and are key terms congruently rendered across texts?; have the most important works been completely translated, or are there others which could excite scholarly and sociological interest were they taken out of the German?; have works already in English been sufficiently and accurately annotated?

Questions of this sort are actually pre-hermeneutical in nature, that is, they must precede discussion and debate about the interpretation of Weber's work itself. Yet without complete, reliable translations, scholarship is forever strapped by various levels of inadequacy, if not outright inaccuracy. Sixteen years ago Guenther Roth remarked that David Easton had written an entire book based on an assumption about Weber which was patently wrong due to Easton's reliance upon partial translations (Roth, 1968:ciii). Roth could have as easily chosen from a raft of American sociologists who over the years have interpreted Weber believing their hermeneutics to be adequate, yet all the while dealing. with fragments of the work they sought to characterize comprehensively. One can only hope that a variorum edition of Weber's works in English will actually appear. If Weber is to continue as a leading theoretical and substantive source for American social science, it would seem time to create a complete edition of consistent, annotated translations. When such a tool is available bogus arguments over the nature of "true" Weberianism can be laid to rest, and the work of the century's foremost social scientist will at last be prepared for its own theoretical obsolescence.
The Unknown Max Weber

\section{FOOTNOTES}

1. Recent books in English exclusively on Weber or relying heavily on his ideas in clude: Stanislav Andreski, Max Weber's Insights and Errors (RKP, 1984) Yoshio Atoji, Sociology at the Turn of the Century: On G. Simmel, in Com parison with F. Toennies, M. Weber, and E. Durkheim (Tokyo: Dobunkan Pub lishing Co., 1984), pp. 45-95; Rogers Brubaker, The Limits of Rationality: An Essay on the Social and Moral Thought of Max Weber (Allen and Unwin 1984); Robert Eden, Political Leadership and Nihilism: A Study of Weber and Nietzsche (University Presses of Florida, 1984); Franco Ferrarotti, Max Weber and the Destiny of Reason (M.E. Sharpe, 1982); Kathi Friedman, Legitimation of Social Rights and the Western Welfare State: A Weberian Perspective (University of North Carolina Press, 1981); Ronald Glassman and Vatro Murvar, eds., Max Weber's Political Sociology (Greenwood, 1984); Jürgen Habermas, The Theory of Communicative Action, Vol. 1 (Beacon Press, 1984, pp. 143286); Susan Hekman, Weber, the Ideal Type, and Contemporary Social Theory (University of Notre Dame Press, 1983); Toby Huff, Max Weber and the Methodology of the Social Sciences (Transaction Books, 1984); Anthony Kronman, Max Weber (Stanford University Press, 1983); Karl Loewith, Max Weber and Karl Marx (Allen and Unwin, 1982); Gordon Marshall, In Search of the Spirit of Capitalism (Columbia University Press, 1982); J.G. Merquior, Rosseau and Weber (RKP, 1980); E.G. Midgley, The Ideology of Max Weber: A Thomist Critique (Littlefield, Adams, 1983); Hisao Otsuka, The Spirit of Capitalism: The Max Weber Thesis in an Economic Historical Perspective (Tokyo: Iwanami Shoten, 1982); Gianfranco Poggi, Calvinism and the Capitalist Spirit (University of Massachusetts Press, 1981); Wolfgang Schluchter, The Rise of Western Rationalism (University of California Press, 1981); Arthur Schweitzer. The Age of Charisma (Nelson Hall, 1984); Bryan Turner, For Weber: Essays on the Sociology of Fate (RKP, 1981); Stephen Turner and Regis Factor, Max Weber and the Dispute over Reason and Value (RKP, 1984). Forthcoming books include the modern classic by Wolfgang Mommsen Max Weber and German Politics, 1890-1920 (Chicago; 1984).

2. I do not want to argue at this point with the claim, inspired by Schleiermacher and perfected in Dilthey's hermeneutics, that competent interpretation must spring from comprehension of a total lifework. While it is probably true that one can legitimately put to use various of Weber's ideas without knowing the entirety, this issue diverges from my simpler, pre-hermeneutical point: that there exist important works, many "empirical" in nature, which American sociology knows little about, and that would repay examination. That coming to terms with the entire corpus would improve the quality of exegesis can hardly be doubted, but, again, this viewpoint originates in a debate over interpretation, the substance of translations, and so on, to which the subject presently being treated is preliminary.

A related matter with which this paper does not deal directly concerns the claim, often heard, that "serious" Weber scholars invariably use the German texts, so translations are not in themselves problematic for this select 
group; and furthermore, the rest of the discipline is uninterested. While the latter statement may be quite true, the former is based on two fallacies. First, Weber's German is difficult even for disciplined native readers of the language, and owing to its horrendous internal structure and Weber's penchant for underreferencing and underparagraphing, even conscientious "Weber scholars" might well be tempted to seek clarification in existing translations. Second, the Ger man editions are unreliable in many places. Not until 1976, in fact, was there a German edition (the fifth) of Economy \& Society as textually accurate as the English translation of 1968 . Though a variorium edition is now in preparation in Germany-33 volumes projected, from J.C.B. Mohr (Paul Siebeck)-translations still remain at points as good or better than some existing German editions, i.e., those which Winckelmann has not re-edited completely.

3. Widespread attack upon Parsons' interpretation of various theorists, especially Weber and Durkheim, has recently produced the assertion from apologists that his first book should not be evaluated as "broad-gauged dissection," but rather as a statement of quite limited theoretical aims. This new-found modesty is both indefensible on textual grounds and historically uncharacteristic of Parsons and his school. And whatever his intentions, it is by now accepted that between 1937 and the early 1960's, Parsons' version of classical theory became orthodoxy, advanced both through his writings and his teaching. His work must be taken as pivotal to the American understanding of Weber, at least until the 1970's.

4. I have cited the English translations, extrapolating from Parsons' own footnotes. Of course, he used the German texts in most cases. It should be emphasized that Parsons' interpretation of Weber is not in itself in question here, but rather his selective use of primary sources.

5. The Protestant Ethic and the Spirit of Capitalism, translated by Talcott Parsons (New York: Scribner's Sons, 1958), pp. 212, 222, 226, 229. Weber writes, "On the attitude of Port Royal and the Jansenists to the calling, see now the excellent study of Dr. Paul Honigsheim, Die Staats- und Soziallenhren der französischen Jansenisten im 17ten Jahrhundert (Heidelberg Historical Dissertation, 1914. ...), p. 212. He later called it "an acute analysis," p. 229.

6. Max Weber: A Biography, translated by Harry Zohn (New York: Wiley-Interscience, 1975), pp. $370,454,455$.

7. "Max Weber als Soziologie," Kölner Vierteljahrshefte für Sozialwissenschaften, Vol. 1, No. 1 (1921), pp. 32-41, and "Erinnerungen an Max Weber," Kölner Zietschrift für Soziologie und Sozialpsychologie, 15 (1963), pp. 161-271, both translated for the first time in On Max Weber, pp. 125-133 and 1-122 respectively.

8. Talcott Parsons, The Structure of Social Action (New York: McGraw-Hill, 1937), pp. 500-694, plus dozens of later works; H.H. Gerth and C. Wright
Mills, trans., and eds., From Max Weber (New York: Oxford University Press, 1946), pp. 3-74; Reinhard Bendix, Max Weber: An Intellectual Portrait (New York: Anchor Books, 1962). Others include Karl Loewenstein, Max Weber's Political Ideas in the Perspective of Our Time (Amherst: University of Massachusetts Press, 1966), pp. 91-104, and Arthur Mitzman, The Iron Cage: An Historical Interpretation of Max Weber (New York: Grosset and Dunlap, 1971).

9. Rural Sociology 11:3 (Sept. 1946): 207-17. Lead article.

10. One of Weber's essays on Russia has recently been translated for the first time "The Prospects of Liberal Democracy in Tsarist Russia," in Weber: Selections in Translation, ed. by W.G. Runciman, trans. by Eric Matthews (Cambridge: Cambridge University Press, 1978), pp. 269-284. Weber typically used his thorough knowledge of agrarian economics to comment upon the political futures of Poland, Russia, and Prussia, thus giving his analyses remarkable depth. The contemporary stylistic equivalent is perhaps Barrington Moore's Social Origins of Dictatorship and Democracy (Boston: Beacon Press, 1966).

11. Of the few appreciable statements about Weber's political sociology of Russia (as opposed to his agrarian sociology), the most recent and detailed is David Beetham, Max Weber and the Theory of Modern Politics (London: Allen and Unwin, 1974), Chapter 7, pp. 183-214. This supplements Richard Pipes, "Max Weber on Russia," World Politics 7:3 (April 1955): 371-401.

12. Q.J. Munters, "Max Weber as Rural Sociologist," Sociologia Ruralis 12:2 (1972): 129-146. This essay does include a useful bibliography of everything Weber wrote which touches upon rural sociology, plus a demonstration of the fact that American text writers on the subject have failed to notice Weber. There are nine explicit references to Honigsheim in Munters' short piece.

13. "Max Weber as Applied Anthropologist," Applied Anthropology: Problems of Human Organization (long since known as Human Organization) $7: 4$ (Fall 1948): $27-35$.

14. Agricultural History 23:3 (July 1949): 179-213.

15. Honigsheim is especially keen in showing the interrelation of Weber and Oppenheimer. At around the same time, he enlarged upon the importance of the latter, a neglected figure, in H.W. Barnes, An Introduction to the History of Sociology (Chicago: University of Chicago Press, 1948), pp. 332-352: "The Sociological Doctrines of Franz Oppenheimer: An Agrarian Philosophy of History and Social Reform."

16. Church History 19 (1950): 219-239.

17. Jugendbriefe, 1876-1893 (Tübingen: Mohr, 1936) and Max Weber: Werk und Person, ed. by Eduard Baumgarten (Tübingen: Mohr, 1964). Baumgarten is in 
Mid-American Review of Sociology

possession of many letters concerning Weber's private life which he has not yet published. Interest in these documents was stimulated by Mitzman's book (mentioned above) and by Martin Green's The von Richthofen Sisters (New York: Basic Books, 1974).

\section{REFERENCES}

Baumgarten, E. (ed.)

1964 Max Weber: Werk und Person. Tübingen: Mohr-Siebeck.

Bendix, R.

1961 Max Weber: An Intellectual Portrait. New York: Anchor Books.

Cohen, J, L. Hazellrigg, and W. Pope

1975 “De-Parsonizing Weber: A Critique of Parsons' Interpretation of Weber's Sociology." American Sociological Review 40:1 (April):229-241.

Green, M.

1974 The Von Richthofen Sisters: The Triumphant and the Tragic Modes of Honigsheim, P ove. New York: Basic Books.

1946 "Max Weber as Rural Sociologist." Rural Sociology 11:3 (September): 207-218.

1948 "Max Weber as Applied Anthropologist." Applied Anthropology 7:4 (Fall): 27-35.

1949 "Max Weber as Historian of Agriculture and Rural Life." Agricultural History 23:3 (July): 179-213.

1950 "Max Weber: His Religious and Ethical Background and Development." Church History 19:219-239.

Käsler, D.

1975 "Max Weber-Bibliographie." Kölner Zietschrift für Soziologie und Sozialpsychologie 27 (December): 703-730

Marx, K. and F. Engels

1975-present Collected Works. New York: International Publishers.

Oberschall, A.

1965 Empirical Social Research in Germany, 1848-1949. New York: Basic Books.

Parsons, $\mathrm{T}$.

1937 The Structure of Social Action. New York: MacMillan.

Roth, G.

1968 "Introduction," pp. xxvii-civ, in Max Weber, Economy and Society. New York: Bedminster Press.

1976 "History and Sociology in the Work of Max Weber." British Journal of Sociology 27:3 (September): 306-318.

Seyfarth, C. and G. Schmidt

1977 Max Weber Bibliographie: Eine Dokumentation der Sekundarliteratur. Stuttgart: Enke.

\section{The Unknown Max Weber}

von Schelting, A.

1934 Max Webers Wissenschaftlehre: Das logische Problem der historischen Kulturerkenntnis. Tübingen: Mohr-Siebeck.

Weber, M

1926 Max Weber: Ein Lebensbild. Tübingen: Mohr-Siebeck. [Translated into English as Max Weber: A Biography. Trans. by H. Zohn. New York John Wiley, 1975.]

\section{WEBER'S WORKS IN GERMAN}

1891 Die Römische Agrargeschichte in ihrer Bedeutung für das Staats-und Privatrecht. 287 pp. Stuttgart: Enke. Reprinted: Amsterdam: P. Schippers, 1962; also as part of the "Ancient Economic History Series" ed. by Moses Finley. Salem, NH: Ayer, Co., 1980.

1892 "Die Verhältnisse der Landarbeiter im ostelbischen Deutschland." Schriften des Vereins für Sozialpolitik 55:1-891. Leipzig: Duncker and Humblot.

1895- "Die Ergebnisse der deutschen Börsenenquete." Zietschrift für das

1896 Gesammte Handelsrecht 43:83-219; 457-514; 44:29-74; 45:69-156.

1909 "Agrarverhältnisse im Altertum." Pp. 52-188 in Handwörterbuch der Staatswissenschaften, ed. by J. Conrad. Jena: Fischer. [Reprinted in GAzSuW: 1-288.

1920- Gesammelte Aufsatze aur Religionssoziologie. Mohr-Siebeck, 3 vol-

1921 umes: I (1920), 573 pp.; II (1921), 378 pp.; III (1921), 442 pp. [ Vol I, 6th printing: 1972; Vol. II, 5th printing: 1972; Vol. III, 6th printing: 1976.

1921a Gesammelte Politische Schriften. Munich: Drei Masken Verlag. [2nd edition: Mohr-Siebeck, 1958, 593 pp.; 3rd edition: Mohr-Siebeck, 1971, 621 pp.] 1st ed.: 451 pp.

1921b Grundriss der Sozialökonomik. III. Abteilung. Wirtschaft und Gesellschaft. (Part I). 180 pp. Tübingen: Mohr-Siebeck.

921c Die rationalen und soziologischen Grundlagen der Musik. 95 pp. Munich: Drei Masken Verlag. [2nd edition: 1924. New edition: Tübingen: Mohr-Siebeck, 1972; 77 pp.]

1922a Gesammelte Aufsätze zur Wissenschaftslehre. 579 pp. Tübingen: MohrSiebeck. [2nd edition: 1951, 688 pp.; 3rd edition: 1968, 613 pp.; 4th edition: 1973, 613 pp.] 
1922b Grundriss der Sozialökonomik. III. Wirtschaft und Gesellschaft. Ed. by Marianne Weber. 840 pp. Tübingen: Mohr-Siebeck. [2nd edition: 1925, 892 pp.; 3rd edition: 1947, 892 pp.]

1923 Wirtschaftsgeschichte: Abriss der Universalen Sozial- und WirtschaftsGeschichte. Ed. by S. Hellman and M. Palyi. 348 pp. Berlin: Duncker and Humblot. [2nd edition: Munich: Duncker and Humblot, 1924: 348 pp.; 3rd edition: 1958, 355 pp.]

1924a Gesammelte Aufsätze aur Sozial- und Wirtschaftseschichte. Tübingen: Mohr-Siebeck. 556 pp.

1924b Gesammelte Aufsätze aur Soziologie und Sozialpolitik. 518 pp. Tübingen: Mohr-Siebeck

1936 Jugendbriefe. Ed. by Marianne Weber. 375 pp. Tübingen: Mohr-Siebeck.

1947 Schriften zur theoretischen Soziologie, zur Soziologie der Politik und Verfassung. Ed. by M. Graf zu Solms. 288 pp. Frankfurt: Schauer.

1956a Soziologie. Weltgeschichtliche Analysen. Politik. Ed. by J. Winckelmann. 576 pp. Stuttgart: A. Kröner. [2nd edition: 1960, 580 pp.; 3rd edition: 1964, 580 pp.; 4th edition: 1968, 582 pp.; 5th edition: 1973 , 584 pp.

1956b Staatssoziologie. Ed. by J. Winckelmann. 129 pp. Berlin: Duncker and Humblot. [2nd edition: 1966, 140 pp.]

1956c Wirtschaft und Gesellschaft: Grundriss der verstehenden Soziologie. Ed. by J. Winckelmann. 4th edition: 1033 pp. [4th rev. edition: 1972, 942 pp.; 5th rev. edition: 1976, 1171 pp., 3 vols.]

1960 Rechtssoziologie. Ed. by J. Winckelmann. 386 pp. Berlin: HermannLuch terhand. [2nd edition: 1967, 452 pp.]

1964a Max Weber: Werk und Person. Ed. by Eduart Baumgarten. 720 pp. Tübingen: Mohr-Siebeck. [Includes about 143 pages of material unavailable elsewhere.]

1964b Wirtschaft und Gesellschaft: Grundriss der verstehenden Soziologie. Ed. by J. Winckelmann. 1102 pp. 4th edition. 2 volumes. Köln: Kiepenheuer und Witsch. ["Student edition," paperback]

1968a Methodologische Schriften. Ed. by J. Winckelmann. Frankfurt: Fischer. 362 pp. 1968b Die protestantische Ethik II: Kritiken und Antikritiken. Ed. by J. Winckelmann. Munich: Siebenstern. 400 pp.

1972 Wirtschaft und Gesellschaft: Grundriss der verstehenden Soziologie. 5th rev. edition in 1 volume, 868 pp. Ed. by J. Winckelmann. Tübingen: Mohr-Siebeck.

1976 Wirtschaft und Gesellschaft: Grundriss der verstehenden Soziologie. 5th rev. edition, plus 1 volume of annotations by J. Winckelmann of 303 pp.; total 1,171 pp. Tübingen: Mohr-siebeck.

1982 Max Weber Gesamtausgabe. 33 volumes projected. Ed. by H. Baier, et al. Tübingen: J.C.B. Mohr (Paul Siebeck).

\section{WEBER'S WORKS IN ENGLISH}

1927 General Economic History. Trans. by F.H. Knight. 276 pp. London: Allen and Unwin. [Reprinted, Glencoe: Free Press, 1950; New York: Collier Books, 1961; New York: Free Press, 1966; New York, Transaction Books, forthcoming]

1930 The Protestant Ethic and the Spirit of Capitalism. Trans. by T. Parsons. London: Allen and Unwin. 284 pp. [Reprinted, New York: Scribner's, 1958]

1946 From Max Weber: Essays in Sociology. Trans., ed., and with an introduction by H.H. Gerth and C.W. Mills. 467 pp. New York: Oxford University Press.

1947 The Theory of Social and Economic Organization. Trans. by A.M. Henderson and T. Parsons. 429 pp. New York: Oxford University Press. [Reprinted, New York: Free Press, 1964]

1949 The Methodology of the Social Sciences. Trans. and ed. by E. Shils and H. Finch. 188 pp. New York: Free Press, 1949

1950 "The social causes of the decay of ancient civilization." Trans. by C Mackauer. Journal of General Education 5:75-88. [Reprinted in 1971b]

1951 The Religion of China. Trans. and ed. by H. Gerth. 297 pp. Glencoe: Free Press. [Reprinted, New York: Free Press, 1968]

1952 Ancient Judaism. Trans. and ed. by H.H. Gerth and D. Martindale. Glencoe: Free Press. 461 pp. [Reprinted, New York: Free Press, 1967]

1954 On Law in Economy and Society. Ed. and annotated by M. Rheinstein Trans. by M. Rheinstein and E. Shils. Cambridge: Harvard University Press. [Reprinted, New York: Simon and Schuster, 196?, pb] 356 pp. 
1956 "Max Weber on Bureaucratization in 1909" Pp. 125-131 in J.P. Mayer, Max Weber and German Politics, 2nd ed. London: Faber and Faber.

1958a The City. Trans. and ed. by D. Martindale and G. Neuwirth. 230 pp. Glencoe: Free Press. [Reprinted, New York: Free Press, 1966]

1958b The Rational and Social Foundations of Music. Ed. by D. Martindale and J. Riedel Trans, by D. Martindale, J. Riedel, and G. Neuwirth. 140 pp. Carbondale: Southern Illinois University Press. [Reprinted, 1969, $\mathrm{pb}$

1958c The Religion of India. Trans. and ed. by H.H. Gerth and D. Martindale. 338 pp. Glencoe: Free Press. [Reprinted, New York: Free Press, 1967, $\mathrm{pb}]$

1962 Basic Concepts in Sociology. Trans. and with introduction by H.P. Secher. 123 pp. New York: Philosophical Library. [Reprinted, Secaucus: Citadel Press, 1972, pb]

1963a Max Weber: Selections from His Work. Ed. by S.M. Miller. 88 pp. New York: Thomas Crowell.

1963b The Sociology of Religion. Trans. by E. Fischoff. 286 pp. Boston: Beacon Press. [Reprinted, 1964, pb]

1967 “A Letter from Max Weber." Trans. by B.B. Frye. Journal of Modern History 39:2 (June): 119-125. [unavailable elsewhere]

1968a Economy and Society: An Outline of Interpretive Sociology. Partially trans. and ed. by G. Roth and C. Wittich. 3 vols., cviii +1469 pp. + lxiv. New York: Redminster Press. [Reprinted, Berkeley:- University of California Press, 1979]

1968b Max Weber on Charisma and Institution Building. Ed. and introduced by S.N. Eisenstadt. 309 pp. Chicago: University of Chicago Press.

1970 A Translation of Max Weber's “Ueber einige Kategorien der verstehenden Soziologie" (Essay on some categories of interpretive sociology). M.A. Thesis, E.E. Graber. Norman: University of Oklahoma, 1970. $125 \mathrm{pp}$.

1971a "Max Weber on Race and Society." Trans. by J. Gittleman. Introduction by B. Nelson. Social Research 38:30-41. [Trans. from GAzSuS: 456-462] 1971b Max Weber: The Interpretation of Social Reality. Ed. and introduction by J.E.T. Eldridge. 190 pp. New York: Scribner's; reissued, Schocken, 1980. [Contains a translation of some of Weber's industrial sociology unavailable elsewhere; and "Socialism."]

1972 "Georg Simmel as Sociologist." Trans. and introduction by D.N. Levine. Social Research 39:1 (Spring): 155-163.

1973 "Max Weber on Church, Sect, and Mysticism." Trans. by J. Gittleman. Sociological Analysis 34:2 (Summer): 140-149. [Trans. from GAzSuS: 462-470]

1974 On Universities: The Power of the State and the Dignity of the Academic Calling in Imperial Germany. Trans., ed., and introduction by $\mathrm{E}$. Shils. Chicago: University of Chicago Press.

1975 "Marginal Utility Theory and 'The Fundamental Law of Psychophysics'." Trans. by L. Schneider. Social Science Quarterly 56:1 (June) 21-36. [Trans. from GAzW: 384-399]

1975b Roscher and Knies: The Logical Problems of Historical Economics Trans. and introduction by G. Oakes. 281 pp. New York: Free Press.

1976 The Agrarian Sociology of Ancient Civilizations. Trans. and introduction by R.I. Frank. 411 pp. London: New Left Books.

1977 Critique of Stammler. Trans. and introduction by G. Oakes. 182 pp. New York: Free Press.

1978a "Anti-critical Last Word on The Spirit of Capitalism." Trans. by W.M. Davis. American Journal of Sociology 83:5 (March): 1105-1131. [Trans. from Die protestantische Ethik II, 283-345]

1978b Max Weber: Selections in Translation. Ed. by W.G. Runciman. Trans. by E. Matthews. New York: Cambridge University Press. 394 pp. [Al] translations are Matthews'. About 38 pages of material is unavailable elsewhere.]

1980 "The National State and Economic Policy (Freiburg Address)." Economy and Society 9:428-449.

1981 General Economic History. Introduction by I. Cohen. New Brunswick: Transaction Books. [Uses original Knight translation]

1981 "Some Categories of Interpretive Sociology." Trans by E. Graber. Sociological Quarterly 22:2, 151-180. 